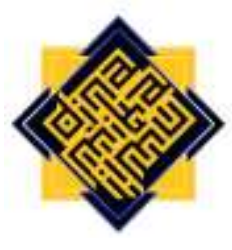

\title{
Effect of Supervisory Leadership on Discipline, Dedication and Its Implications on Teaching Competence of English Teachers in the Digital Era
}

\author{
Masrur \\ Faculty of Cultural Sciences \\ Mulawarman University Samarinda, Indonesia \\ e-mail: masruryahyaalwi@gmail.com
}

\begin{abstract}
For this study, the focus will be on evaluating the impact of supervisory leadership on the professionalism of Samarinda's English instructors in the cyber era. MTs principals and English instructors were the subjects of the investigation. A descriptive quantitative technique is adopted in this study. Observation, questionnaires, and documentation were used for data collection, and regression is used for data analysis. There were 110 participants in this study's population, which included principals and English teachers from public and private MTs in Samarinda. As a result of the need for observation and knowledge, the study was conducted at public and private MTs throughout Samarinda, with the purpose of examining the Effect of Supervisory Leadership on Discipline and Dedication and its Implications on Improving the Teaching Competence of English Teachers in Public and Private MTs throughout Samarinda during the Digital Era. The findings demonstrate that supervisory leadership through discipline indicates an indirect and significant impact on the teaching competency of English teachers in both public and private MTs in Samarinda. Furthermore, these findings demonstrate that the supervisory leadership, as evidenced by his or her dedication, has a substantial impact on the teaching competency of English teachers in both public and private MTs across Samarinda.
\end{abstract}

Keywords: dedication, discipline, supervisory leadership, teaching competence 


\section{Masrur}

\section{A. Introduction}

In the world of education, the function of a teacher is critical, but in light of the challenges of global existence, the task of teachers is more complicated (DarlingHammond et al., 2017). Teachers must have pedagogical competency in order to establish dynamic and successful learning environments (Saleh et al., 2019). Pupil understanding, planning and implementation, and assessment of the attainment of learning are all aspects of pedagogic competence as outlined in article 28 paragraph 3 point (a). This includes developing students' abilities to realize some factors. The competence of pedagogic of the teachers is reflected in the quality of their students' learning.

During the learning process, the teacher's responsibility should include not only the transmission or transformation of knowledge but also the development of the students' personalities in an integrated manner (Campbell, 1996). In addition to imparting instructional materials, teachers are also adept under shaping the personality, character, and conscience of pupils in their care. To address this issue, one of the most effective approaches is to develop pedagogic competency in the classroom. Good pedagogic competence can be determined by a teacher's capacity to comprehend the principles of learning, learning theory, and mastery of instructional materials, among other characteristics (Banjo, 2004).

There must be a careful balancing act between the changing times and new programs that are relevant to the curriculum's needs and demands. Educators may find it challenging to choose the proper learning situation, not to mention that new curriculums bring changes in goals, methods, and strategies that are tough to comprehend (Banjo, 2004). Learning methods, strategies, and evaluations can be challenging for certain educators to implement, while students in the millennial era can be tough for educators to deal with, making it difficult for educators to implement learning programs (Oghuvbu, 2007).

There must be assistance from all parts of the school, including the principal, in this increasingly difficult situation. Academia supervision is one type of learning process supervision. While performing his duties as a supervisor, the principal must focus on the development of each teacher's personality, their ongoing professional growth, and their progress in the learning process and subject matter mastery. It has been found in numerous studies (Afe, 2020) that academic supervision significantly improves pedagogic competence.

Principals must possess strong leadership and school administration abilities (Klaassen \& Maslovaty, 2010). In order for learning and teaching to go well, all school members must put forth effort in order for them to have fun and feel satisfied at school. As a result, the principal must have the capacity or skill to serve as an educational developer and mentor in order to ensure that everyone is making the most of their abilities while carrying out their responsibilities. In addition to his or her role as a managerial supervisor, the principal also serves as an academic supervisor for the school. As an academic supervisor, the principal has a responsibility to assist teachers in becoming more 
professional so that they can improve the overall quality of the learning experience for all students. Academic supervision activities are not used to evaluate the performance of teachers (Afe, 2020).

Academic supervisory is a set of works that are designed to help teachers in improving their capacities to control the learning process in order to achieve learning objectives in the classroom (Furlong, et. al., 2000). As a result, academic supervision does not, in essence, evaluate the work of instructors in terms of controlling the learning process, but rather assists teachers in the development of their professional competencies. Academic supervision, in addition to having an impact on pedagogic competence, can also have an impact on lecturer attainment. According to the findings, supervisory intentions have a favorable impact on the achievement of lecturers in the classroom (Sudarjat et al., 2015).

In addition to being an important factor in determining the quality of instruction, the attainment of an instructor is also an important factor in education. The teacher's performance as an educator is carried out by the instructor while he or she is fulfilling the responsibilities of a teacher (Furlong, et. al., 2000). Educator performance has a direct impact on educational results, as the teacher is the person who interacts most directly with pupils over the course of learning. A teacher's performance is influenced by the setting in which he or she works. As a result, in addition to instructors who can increase the quality of their own work, the surrounding environment, particularly schools like principals, must be able to motivate and empower them to produce high-quality work and function as professional teachers (Furlong, et. al., 2000).

In addition to being a significant aspect in determining the quality of instruction, instructor achievement is also a crucial aspect of education. The teacher's performance as an educator is carried out by the instructor while he or she is fulfilling the responsibilities of a teacher. Educator performance has a direct impact on educational results, as the teacher is the person who interacts most directly with pupils over the course of learning. A teacher's performance is influenced by the setting in which he or she works. As a result, in addition to instructors who can increase the quality of their own work, the surrounding environment, particularly schools like principals, must be able to motivate and empower them to produce high-quality work and function as professional teachers (Roseline \& Konya, 2019).

The principal's duty as a leader requires him to direct others, which is enjoyable for the instructor. As a school principal, you must always develop excitement and motivation in order to create a harmonious relationship with those you lead, so boosting the high quality of work and producing good work performance. Those who can focus on their subordinates' wants and ambitions are not focused on their own power, therefore their job happiness is always met. Self-efficacy influences job happiness and performance.

Self-efficacy, the belief that one can accomplish one's objectives and mastery, as well as the belief that one can learn new skills and overcome challenges, are all aspects of one's competence that can be measured and are linked to success expectations (Furlong, et. al., 2000). Teacher confidence and job satisfaction and excitement for success are 
impacted by this belief in one's own abilities. Even when confronted with difficulties and failures, a teacher with low self-efficacy lacks confidence in his or her ability to succeed. It is believed that a teacher with a high sense of self-efficacy will do an excellent job fulfilling his or her responsibilities (Streiner, 2005).

Several factors have been linked to low teacher self-efficacy in the previous study (Roseline, \& Konya, 2019; Saleh, 2019). Teaching abilities, knowledge, professional attitude, capacity to choose, create, and use media, ability to design curricular dynamics, and provide effective examples are all characteristics of good teachers. A teacher's role in achieving educational goals in schools includes being ready to teach. The quality of teaching and teachers is a hot topic that must be handled properly (Roseline \& Konya, 2019).

In order to educate students, teachers and schools must adhere to certain guidelines. In the context of Indonesian education and schooling, to be more precise. In order to improve teaching efficiency, one of the most interesting characteristics of teachers is selfefficacy. A unique phenomenon, teacher self-efficacy can be considered as one of the factors that contribute to an efficient learning and teaching procedure. A teacher's selfefficacy has been shown to influence their ability to teach effectively (Berg, 1989). Selfefficacy, on the other hand, can boost an individual's performance (Jolayemi, 2008; Mangkunegara, 2015), Self-effectiveness shows to have an influence on teacher performance in studies of Susanti et al. (2020) and Sulyman (2020).

\section{Research Questions}

To guide the research procedures of this study, the following research questions were sought to answer:

1) Is there any direct impact of the supervisory leadership on the discipline of English teachers of MTs Samarinda?

2) Is there any direct impact of supervisory leadership on the dedication of English teachers of MTs Samarinda?

3) Is there any significant influence of supervisory leadership on teacher competence of English teachers of MTs Samarinda?

4) Is there any direct significant effect of discipline on teacher competence of English teachers of MTs Samarinda?

5) Is there any direct significant effect of dedication on teacher competence of English teachers of MTs Samarinda?

6) Is there any indirect supervisory leadership through discipline that has a significant influence on teacher competence of English teachers of MTs Samarinda?

7) Is there any indirect supervisory leadership through dedication that has a significant influence on teacher competence of English teachers of MTs Samarinda?

\section{Hypothesis}

The statistical hypotheses of this study are defined as follows: 
$\mathrm{Ho}_{1}$ : Directly there is a significant influence of the supervisory leadership on the discipline of English teachers of MTs Samarinda.

$\mathrm{Ho}_{2}$ : There is a direct significant influence of supervisory leadership on the dedication of English teachers of MTs Samarinda

$\mathrm{Ho}_{3}$ : Directly there is a significant influence of supervisory leadership on teacher competence of English teachers of MTs Samarinda.

$\mathrm{Ho}_{4}$ : There is a direct significant effect of discipline on teacher competence of English teachers of MTs Samarinda.

$\mathrm{Ho}_{5}$ : There is a direct significant effect of dedication on teacher competence of English teachers of MTs Samarinda.

$\mathrm{Ho}_{6}$ : Indirectly, the principal's leadership through discipline has a significant influence on teacher competence of English teachers of MTs Samarinda.

$\mathrm{Ho}_{7}$ : Indirectly, the principal's leadership through dedication has a significant influence on teacher competence of English teachers of MTs Samarinda.

\section{B. Theoretical Framework}

\section{Teacher Discipline}

Discipline, according to Day (2002) is described as an exercise or education in morality and spirituality as well as character development. We need to show our employees that we care about their well-being by adhering to norms and policies. As a part of an organization or a group's mission, this training or education is essential. Craig \& Martin. (2019) assert that school discipline reforms have increasingly sought to limit the use of suspensions, which are punishments that exclude misbehaving students from class.

According to Reinecke, et. al, (2018), self-management is essential for teachers and other education personnel in order to ensure that all regulations that have been agreed upon with the school are not easily violated or abandoned on purpose, and this will work well if each teacher has self-management in carrying out their duties. Teachers who maintain high levels of discipline will, in turn, encourage higher levels of performance. If the organization and the people who are a part of it are successful, then performance is a good indicator of that success. Workers, both management and non-managerial, have an interest in the organization (Hitt, et. al., 2001). Thus, performance management should be used collectively and cooperatively to prevent poor performance and to apply strategies of working together to increase performance. Managers must also monitor their superiors' performance because they are accountable to them.

Teachers' performance and discipline can be improved thanks in large part to the efforts of principals (Khasanah et al 2019; Apriana et al, 2019; Andriani et al, 2018; Renata et al, 2018). Teachers, administrators, and students need principals with high levels of emotional intelligence who can implant, promote, and strengthen mental, moral, physical, and creative qualities in them (Murtiningsih et al, 2019). The principal's position must be convincing and exemplary so that it can serve as a model for teaching discipline. Teachers are compelled to act in the best interest of the workplace or school if their bosses don't allow them to express their views. Teachers' work ethics will suffer as a result of this. 
Masrur

Teachers need to be trusted in order for them to take responsibility for their work, which will lead to better teacher performance discipline (Hewitt, et. at., 2019).

\section{Teacher Dedication}

Dedicated personnel, according to Sulyman (2020), should not be separated from their colleagues since it affects the amount to which they carry out their official obligations and the general performance of the firm. In the opinion of Roseline \& Konya (2019), employee dedication is essential to the success of a firm. Every company needs to put employee devotion at the top of its priority list. All things being equal, an organization with a large number of dedicated personnel is more efficient than an organization with a small number of dedicated people. Dedicated employees can be identified in the following ways, according to Hewitt, et. at., (2019). Additionally, they consistently display behaviors that promote organizational success while also spreading positive information about the company and displaying a strong desire to identify with it.

According to Mart (2013), devoted teachers have an easier time enticing pupils to engage in active learning and directing the development of their intellectual and moral character. Committed educators, on the other hand, will be eager and excited about their official duties and have an interest in ensuring that their students succeed academically. Teaching is a job that requires dedication, and if a teacher lacks this, their students' education may be put on the back burner (Rahabav, 2016).

\section{Teacher Competence}

Robbins (2001:37) defines competence as the capacity to perform multiple activities in a profession. It is also stated that an individual's ability is produced by two factors: intellectual and physical. Physical ability is required to do jobs that demand stamina, dexterity, strength, and skill. Competency, according to Spencer \& Spencer (2008) is causally related to criterion-referenced effective and/or exceptional performance in a job or scenario. In other words, competence refers to a person's ability to execute at a high level in a specific job or scenario. A person's competence is considered an underlying trait because it is an intrinsic aspect of their personality, which may be used to forecast a person's success in a wide range of situations and work assignments present themselves. A relationship between competence and conduct and performance is referred to as causally connected. Credibility accurately predicts whether an individual's performance will be good or bad, therefore the term "criterion-referenced (Ujiarto, et. al., 2017).

\section{Supervisory Leadership}

Teachers are expected to put up an extra effort in the performance of their duties as supervisors in order to better serve their students' educational needs. The job of a school administrator includes a significant amount of supervision (Mette et al., 2015; Talbert \& McLaughlin, 1994). As a result, the term "supervision" can be used to describe activities designed to assist teachers in doing their duties more effectively. As a result, supervision 
serves as a tool for directing, coordinating, developing, guiding, and regulating others in order to help them meet the objectives they've set for themselves in the classroom.

The purpose of supervision is to develop classroom management practices, monitor curriculum material, and direct instructional and disciplinary activities (Edo \& David, 2019; Egwu, 2015). School monitoring is meant to help students learn, but it also helps teachers and the overall educational environment (Carlos et al., 2017; Wairimu, 2016). Effective teacher supervision requires professionalism, knowledge, abilities, and personality. The supervision program will prioritize participation, instructor support, self-improvement, coaching, and ongoing mentorship (Rahabav, 2016). Principals employ supervision to improve teacher and student outcomes. Supervision is systematic coaching for teachers and other educational staff. As a result, academic supervision must prioritize the development of all teacher competencies (Susanti et al, 2020). Students who serve as supervisors play a significant part in supervision. The connection between lecturers and academic supervisors is complicated, and it is influenced by a variety of dynamic dynamics (Gratrix \& Barrett, 2017).

\section{Research Methodology}

1. Research Design

An investigation into the impact of supervisory leadership on discipline and dedication in public and private MTs in Samarinda is done in the digital age. The study's goal necessitated a quantitative research design. The study uses quantitative methods to test the theory using field data (Creswell, 2014). The study takes place in Samarinda, East Kalimantan. This study's data analysis method is path analysis that implements a multiple linear regression extension that allows for more complex models (Streiner, 2005). According to Retherford \& Choe (2011), route analysis is a technique used to examine the causal relationship between independent and dependent variables in multiple regression.

\section{Sample}

The participants in this study were students and professors at non-PTKI tertiary institutions who were members of the Teachers and Principals of Public and Private MTs in Samarinda City, East Kalimantan, Indonesia, who were also members of the Teachers and Principals of Public and Private MTs. The random sampling technique was used to choose the samples for this study, which resulted in a total of 110 participants.

\section{Data and Sources of Data}

The information used in this study was derived from both primary and secondary sources. Primary data is information that has been gathered directly from respondents through interviews. When compared to primary data, secondary data is gathered directly from the distribution of questionnaires that have been distributed to respondents. The following data gathering strategies were used in this study: 1) distribution of questionnaires, 2) interviews, and 3) production of documentaries. 


\section{Masrur}

\section{Research Instruments}

The data collected from the research sample was gathered via questionnaires. In order to collect data, this study uses a questionnaire produced by the researcher based on the indicators supplied by previous researchers. It includes two questionnaires: one for the Principal and another for the teacher. Two components are required for each. Firstly, the respondent's data is included, and then the items are arranged according to three variables.

Table 1. Research instrument grid

\begin{tabular}{|c|c|c|}
\hline Variable & Indicator & Scale \\
\hline Principal & 1. Giving motivation to work & Interval \\
\hline \multirow[t]{8}{*}{ Leadership } & 2. Discipline coaching & \\
\hline & 3. Giving consultation & \\
\hline & 4. Giving awards & \\
\hline & 5. Make class visits & \\
\hline & 6. Demonstrate exemplary attitude and behavior & \\
\hline & 7. Build active work & \\
\hline & 8. Creative & \\
\hline & 9. Developing the teaching profession & \\
\hline \multirow[t]{5}{*}{$\begin{array}{l}\text { Teacher } \\
\text { Competence }\end{array}$} & $\begin{array}{l}\text { 1. Mastering the material, structure, concept, and scientific } \\
\text { mindset that supports the subjects taught }\end{array}$ & Interval \\
\hline & $\begin{array}{l}\text { 2. Mastering competency standards and basic competencies of } \\
\text { the subjects/fields of development being taught }\end{array}$ & \\
\hline & 3. Develop creatively guided learning materials & \\
\hline & $\begin{array}{l}\text { 4. Continuously develop professionalism by taking reflective } \\
\text { actions }\end{array}$ & \\
\hline & $\begin{array}{l}\text { 5. Utilizing information and communication technology to } \\
\text { communicate and develop themselves }\end{array}$ & \\
\hline Teacher's & 1. Has abundant energy reserves & Interval \\
\hline \multirow[t]{2}{*}{ Dedication } & 2. Willingness to sacrifice & \\
\hline & 3. Always give the best & \\
\hline \multirow[t]{4}{*}{ Teacher Discipline } & 1. Teacher compliance with school rules & Interval \\
\hline & 2. The teacher's punctuality while in the school environment & \\
\hline & 3. Awareness of teachers in carrying out their duties and & \\
\hline & 4. The responsibility of the teacher in carrying out his duties. & \\
\hline
\end{tabular}

\section{The validity of the research instrument}

Questionnaires were sent to 110 respondents, principals, and English teachers from public and private MTs. The validity and dependability of the data were tested. Using the SPSS application and the Product Moment analysis method, we tested the study's validity. It can be observed from the table above that each statement item has a r-count more than or equal to the r-table value and is positive. Thus, the statement item is deemed to be true. Section II. Discipline/Dedication/Teacher Competence Results of Principal's Leadership Reliability Test. 
Table 2. Reliability Statistics

\begin{tabular}{lcc}
\hline \multicolumn{1}{c}{ Variables } & Total Items & Cronbach's $\alpha$ \\
\hline Principal Leadership & 9 & 0.616 \\
Discipline & 4 & 0.749 \\
Dedication & 3 & 0.872 \\
Competence & 6 & 0.762 \\
\hline
\end{tabular}

From the table above, the results of the above analysis found cronbacchs alpha values of $0.616,0.749,0.872$, and 0.762 . So it can be concluded that the items of the research instrument are reliable because they are greater than 0.6 .

\section{Data Analysis}

If you're interested in discovering patterns or making meaning out of a dataset, data analysis is the best way to do so. In this work, path analysis is used as a data analysis tool. Path analysis can be used to examine increasingly complex models as an extension of multiple linear regression (Streiner, 2005). Using route analysis, Retherford \& Choe (2011) claim that an independent variable can have both a direct and indirect effect on the dependent variable in multiple regression. Researchers can make their findings more meaningful by providing a detailed description of their research objectives. The authenticity of the data provided by the participants is confirmed using the triangulation technique, which compares and assesses the trustworthiness of the information collected from each informant. The validity of the data is also checked by comparing it to the most recent published research.

\section{Findings}

\section{Normality Test}

Table 3. Normality Test Results

\begin{tabular}{ccc}
\hline $\begin{array}{c}\text { Unstandardized Residuals } \\
(\mathrm{N}=110)\end{array}$ & KS (Z value) & Sig \\
\hline Model 1 & 0.712 & 0.692 \\
Model 2 & 0.726 & 0.668 \\
Model 3 & 0.491 & 0.969 \\
\hline
\end{tabular}

Based on the normality test table above, the Kolmogorov Smirnov Test is: 1 ) is 0.712 with a 0.692 probability. 2 . The $p$-value above the constant value $=0.05$ implies that the data is normally distributed. If the $\mathrm{p}$-value is greater than 0.05 , the data is normally distributed.

Table 4. Linearity Test Results

\begin{tabular}{lcc}
\hline \multicolumn{1}{c}{ Interaction } & F count & Sig. \\
\hline Discipline * Principal Leadership & 92.701 & 0.000 \\
Dedication * Principal Leadership & 7.794 & 0.006 \\
Teacher competence * Dedication & 24.407 & 0.000 \\
\hline
\end{tabular}

Dinamika Ilmu, Volume 20(2), 2020 


\section{Masrur}

The significance value is used to determine the Deviation from Linearity Sig value (Sig). 2) In equation 2, the Deviation from Linearity Sig value is calculated using the significance value (Sig). > 0.053 ) The Deviation from Linearity Sig value is calculated in equation 3 using the significance value (Sig). $0.054>$ Principal Leadership (X), Discipline (Y1), Dedication $\left(Y_{2}\right)$, and Teacher Competence (Y2) are all linked ( $\left.\mathrm{Z}\right)$.

Table 5. Multicollinearity Test Results

\begin{tabular}{clcc}
\hline \multirow{2}{*}{ Models } & \multicolumn{2}{c}{ Variable } & \multicolumn{2}{c}{ Statistics of Collinearity } \\
\cline { 3 - 4 } & & Tolerance & VIF \\
\hline 1. & Principal Leadership & 1.000 & 1.000 \\
2. & Principal Leadership & 1.000 & 1.000 \\
3. & Principal Leadership & 0.510 & 1.959 \\
4. & Discipline & 0.534 & 1.872 \\
5. & Dedication & 0.932 & 1.073 \\
\hline
\end{tabular}

The following is known from the "Collinearity Statistics" output table: 1 ) In equation 1 , the Principal Leadership variable $(X)$ Tolerance is 1,000 larger than 0.10 . The Principal Leadership variable $(X)$ has a VIF of 1,000 10.00. 2) In equation 1 , the Tolerance value for the Principal Leadership variable $(X)$ is 1,000 larger than 0.10 . The Principal Leadership variable (X) has a VIF of 1,000 10.00. 3) In equation 3, the Principal Leadership variable (X) has a tolerance value of 0.510 , Discipline $\left(Y_{1}\right)$ is 0.534 , and Dedication ( $\left.Y_{2}\right)$ is 0.932 , all of which are greater than 0.10. The VIF values for Principal Leadership (X), Discipline (Y1), and Dedication (Y2) are all less than 10.00. Using the multicollinearity test as a decision-making tool, the regression model shows no signs of multicollinearity.

\section{Partial Test (t-test)}

Table 6. T-Test Results $\mathrm{X} \rightarrow \mathrm{Y}_{1}$

\begin{tabular}{cclccc}
\hline Model & Dependent Variable & Independent Variable & Beta & t count & Sig. \\
\hline 1 & Discipline (Y1) & (Constant) & $-4,873$ & -2.405 & 0.018 \\
& & Principal Leadership & 0.57 & 9,693 & 0.000 \\
& & $(\mathrm{X})$ & &
\end{tabular}

In the table above, the t-test is stated to be important if tcount $>$ ttable $>1.65882$, and non-significant if tcount ttable 1.65882. tcount $9.693>$ ttable 1.65882 shows that Principal Leadership $(X)$ substantially influences Discipline (Y1).

Table 7. T-Test Results $\mathrm{X} \rightarrow \mathrm{Y}_{2}$

\begin{tabular}{cllllc}
\hline Model & Dependent Variable & Independent Variable & Beta & t count & Sig. \\
\hline 2 & Dedication (Y2) & (Constant) & 4.118 & 1,699 & 0.092 \\
& & Principal Leadership & 0.197 & 2,792 & 0.006 \\
& & $(\mathrm{X})$ & & & \\
\hline
\end{tabular}


Table 7 suggests that tcount 2,792 > t-table 1.65882 then a positive and significant effect is identified on supervisory leadership $(X)$ towards dedication (Y2).

Table 8. T-Test Results $X_{1} Y_{1}, \& Y_{2} \rightarrow Z$

\begin{tabular}{cllccc}
\hline Model & Dependent Variable & Independent Variable & Beta & t count & Sig. \\
\hline \multirow{2}{*}{3} & Teacher & (Constant) & 3,470 & 1.630 & 0.106 \\
& Competence $(Z)$ & & & \\
& & Principal Leadership & & & \\
& & $(X)$ & 4,623 & 0.000 \\
& & Discipline $\left(Y_{1}\right)$ & 0.501 & 3.104 & 0.001 \\
& & Dedication $\left(Y_{2}\right)$ & 0.302 & 3,712 & 0.000 \\
\hline
\end{tabular}

With t-count 4,623 > t-table 1.5882, Principal Leadership $(X)$ influences Teacher Competence (Z) partially. In other words, Principal Leadership (X) has a positive and significant impact on teacher competence $(Z)$.

According to the t-count $3.104>t$-table 1.65882, the influence of discipline $\left(\mathrm{Y}_{1}\right)$ on Teacher Competence ( $Z$ ) is positive and significant (t-count 3.104). (Z). This study found that the variable Dedication $\left(Y_{2}\right)$ had a positive and significant effect on Teacher Competence $(Z)$ when t-count 3,712 >t-table 1.65882. (Z).

\section{Determination Coefficient Test}

Table 9. Results of the Coefficient of Determination $X \rightarrow Y_{1}$

\begin{tabular}{cccccc}
\hline Model & $\begin{array}{c}\text { Dependent } \\
\text { Variable }\end{array}$ & $\begin{array}{c}\text { Independent } \\
\text { Variable }\end{array}$ & R & R-Sq & $\begin{array}{c}\text { Adj. R- } \\
\text { Sq }\end{array}$ \\
\hline 1 & Discipline $\left(Y_{1}\right)$ & $\begin{array}{c}\text { Principal Leadership } \\
(X)\end{array}$ & 0.682 & 0.465 & 0.460 \\
\hline
\end{tabular}

The regression process shows that the coefficient of determination (adjusted $R$ square) obtained is 0.46 . This means that $46 \%$ of the variation of the Principal Leadership variable contributes to discipline by $46 \%$, the remaining $54 \%$ is explained by other variables that are not proposed in this study.

Table 10. Results of the Coefficient of Determination $\mathrm{X} \rightarrow \mathrm{Y}_{2}$

\begin{tabular}{cccccc}
\hline Model & $\begin{array}{c}\text { Dependent } \\
\text { Variable }\end{array}$ & $\begin{array}{c}\text { Independent } \\
\text { Variable }\end{array}$ & R & R-Sq & $\begin{array}{c}\text { Adj. R- } \\
\text { Sq }\end{array}$ \\
\hline 2 & Dedication $\left(Y_{2}\right)$ & $\begin{array}{c}\text { Principal Leadership } \\
(X)\end{array}$ & 0.259 & 0.067 & 0.059 \\
\hline
\end{tabular}

The coefficient of determination (adjusted R square) obtained is 0.059 , this means that the Principal Leadership variable contributes $5.9 \%$ to teacher dedication, and the $94.1 \%$ is defined by other variables. 
Masrur

Table 11. Results of the Coefficient of Determination $X \rightarrow Z$

\begin{tabular}{cccccc}
\hline Model & Dependent Variable & $\begin{array}{c}\text { Independent } \\
\text { Variable }\end{array}$ & $\mathrm{R}$ & $\mathrm{R}-\mathrm{Sq}$ & $\begin{array}{c}\text { Adj. } \mathrm{R}- \\
\mathrm{Sq}\end{array}$ \\
\hline 3 & $\begin{array}{c}\text { Teacher } \\
\text { Compentence }(\mathrm{Z})\end{array}$ & $\begin{array}{c}\text { Principal Leadership } \\
(\mathrm{X})\end{array}$ & 0.559 & 0.312 & 0.306 \\
\hline
\end{tabular}

Data show that the coefficient of determination (adjusted $R$ square) obtained is 0.306 , this means that the Principal Leadership variable contributes $30.6 \%$ to teacher competence, while the remaining $69.4 \%$ is explained by other variables not proposed in this study. .

Table 12. Results of the Coefficient of Determination $\mathrm{Y}_{1} \rightarrow \mathrm{Z}$

\begin{tabular}{cccccc}
\hline Model & Dependent Variable & $\begin{array}{c}\text { Independent } \\
\text { Variable }\end{array}$ & R & R-Sq & $\begin{array}{c}\text { Adj. R- } \\
\text { Sq }\end{array}$ \\
\hline 3 & $\begin{array}{c}\text { Teacher } \\
\text { Compentence }(Z)\end{array}$ & Discipline $\left(\mathrm{Y}_{1}\right)$ & 0.369 & 0.136 & 0.128 \\
\hline
\end{tabular}

This data indicates that the coefficient of determination (adjusted $\mathrm{R}$ square) obtained is 0.128 , this means that the discipline variable contributes $12.8 \%$ to teacher competence, while the remaining $87.2 \%$ is explained by other variables not proposed in this study.

Table 13. Results of the Coefficient of Determination $Y_{2} \rightarrow Z$

\begin{tabular}{cccccc}
\hline Model & Dependent Variable & $\begin{array}{c}\text { Independent } \\
\text { Variable }\end{array}$ & R & R-Sq & $\begin{array}{c}\text { Adj. R- } \\
\text { Sq }\end{array}$ \\
\hline 3 & $\begin{array}{c}\text { Teacher } \\
\text { Compentence (Z) }\end{array}$ & Dedication (Y2) & 0.417 & 0.174 & 0.166 \\
\hline
\end{tabular}

The coefficient of determination (adjusted R square) obtained is 0.166 , this means that the discipline variable contributes $16.6 \%$ to teacher competence, while the remaining $83.4 \%$ is explained by other variables not proposed in this study.

Table 14. Results of the Coefficient of Determination $X_{1} Y_{1} \rightarrow Z$

\begin{tabular}{cllccc}
\hline Model & Dependent Variable & \multicolumn{1}{c}{$\begin{array}{c}\text { Independent } \\
\text { Variable }\end{array}$} & R & R-Sq & $\begin{array}{c}\text { Adj. R- } \\
\text { Sq }\end{array}$ \\
\hline 3 & $\begin{array}{l}\text { Teacher } \\
\text { Compentence }(Z)\end{array}$ & $\begin{array}{l}\text { Principal Leadership } \\
(X)\end{array}$ & 0.559 & 0.312 & 0.299 \\
& Discipline $\left(Y_{1}\right)$ & & & \\
\hline
\end{tabular}

The coefficient of determination (adjusted $R$ square) 0.299 means that the supervisory Leadership and Discipline variable contributes $29.9 \%$ to Teacher Competence, and $70.1 \%$ is defined by other variables. 
Table 15. Results of the Coefficient of Determination $X_{1} Y_{2} \rightarrow Z$

\begin{tabular}{cllccc}
\hline Model & Dependent Variable & \multicolumn{1}{c}{$\begin{array}{c}\text { Independent } \\
\text { Variable }\end{array}$} & R & R-Sq & $\begin{array}{c}\text { Adj. R- } \\
\text { Sq }\end{array}$ \\
\hline 3 & $\begin{array}{l}\text { Teacher Competence } \\
(Z)\end{array}$ & $\begin{array}{l}\text { Principal Leadership } \\
(X) \\
\text { Dedication }\left(Y_{2}\right)\end{array}$ & 0.626 & 0.391 & 0.380 \\
\hline
\end{tabular}

This data shows that the coefficient of determination (adjusted R square) 0.380 means that the Supervisory Leadership and Dedication variable contributes $38 \%$ to Teacher Competence, and $62 \%$ is defined by other variables.

\section{Hypothesis Testing}

Direct Effect of Supervisory Leadership On Discipline

$\mathrm{Ho}_{1}$ : Directly there is a significant influence of the supervisory leadership on discipline of English teachers of MTs Samarinda.

The impact of $X$ on $Y_{1}$ indicates a significance value of $X$ is $0.000<0.05$, implying there is a direct significant effect of $X$ on $Y_{1}$.

Direct Effect on Supervisory leadership on dedication

$\mathrm{Ho}_{2}$ : There is a direct significant influence of supervisory leadership on dedication of English teachers of MTs Samarinda

The impact of $X$ on $Y_{2}$ reveals a significance value of $X$ is $0.006<0.05$, saying there is a direct significant effect of $X$ on $Y_{2}$.

Direct effect on Supervisory leadership on teacher competence

$\mathrm{Ho}_{3}$ : Directly there is a significant influence of supervisory leadership on teacher competence of English teachers of MTs Samarinda.

The effect of $Y_{2}$ on $Z$ found the significance value of $Y_{2}$ was $0.000<0.05$, indicating a direct significant effect of $Y_{2}$ on $Z$.

Indirect significant effect of discipline on teacher competence

$\mathrm{Ho}_{4}$ : There is a direct significant effect of discipline on teacher competence of English teachers of MTs Samarinda.

The effect of $Y_{1}$ on $Z$ shows a significance value of $X$ of $0.005<0.05$, meaning there is a direct significant effect of $Y_{1}$ on $Z$.

\section{Direct significant effect of dedication on teacher competence}

$\mathrm{Ho}_{5}$ : There is a direct significant effect of dedication on teacher competence of English teachers of MTs Samarinda. 
Masrur

The impacts of $Y_{2}$ on $Z$ found that the significance value of $Y_{2}$ was $0.000<0.05$, projecting direct significant effect of $Y_{2}$ on $Z$.

\section{Indirect supervisory leadership through discipline}

$\mathrm{Ho}_{6}$ : Indirectly, the supervisory leadership through discipline has a significant influence on teacher competence of English teachers of MTs Samarinda.

The effect of $X$ through $Y_{1}$ on $Z$ indicates the direct effect given by $X$ to $Z$ is 0.574 . While the indirect effect of $X$ through $Y$ on $Z$ is the multiplication between the beta value of $X$

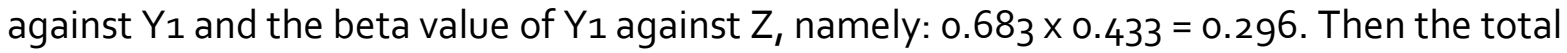
effect given by $X$ to $Z$ is the direct effect plus the indirect effect, namely: $0.574+0.296=$ 0.870 . Based on the results of the above calculation, it is known that the direct influence value is 0.574 and the indirect effect is 0.870 , which means that the indirect effect value is greater than the direct influence value. These results indicate that indirectly $X$ through $Y_{1}$ has a significant effect on $Z$.

\section{Indirectly supervisory leadership through dedication}

$\mathrm{Ho}_{7}$ : Indirectly, the supervisory leadership through dedication has a significant influence on teacher competence of English teachers of MTs Samarinda.

The direct effect of $X$ on $Z$ is known to be 0.483 . The indirect effect of $X$ through $Y_{2}$ on $Z$ is $0.259 \times 0.483=0.125$. The total effect of $X$ to $Z$ is $0.483+0.125=0.608$. Based on the foregoing estimates, the direct influence is 0.483 and the indirect effect is 0.608 , indicating that the indirect effect outweighs the direct influence. These data show that $X$ indirectly affects $Z$ via $Y_{2}$.

\section{E. Discussion}

It may be concluded from the data analysis that the principal's leadership through discipline has a substantial impact on the competency of teachers. This shows that the principal's leadership as the executor of educational supervision, or in other words, as a supervisor, can mediate the increase of teacher competence through the application of discipline.

The findings of this study are reinforced by the fact that the principal plays a significant effect in increasing teacher performance and discipline (Khasanah et al 2019; Apriana et al, 2019; Andriani et al, 2018; Renata et al, 2018). In order to effectively develop, encourage, and strengthen mental and moral values as well as physical and aesthetic values in teachers and administrative personnel as well as pupils, principals need to possess emotional intelligence (Murtiningsih et al, 2019). A persuasive and exemplary attitude must be demonstrated by the principal in order to serve as a model for teacher performance in terms of academics and other subjects. Teachers are compelled to act a priori in the interests of the workplace or the school by principals who do not want to hear their subordinates' ideas. This will have a negative impact on teacher job discipline. 
Simson (2009) also contends that ineffective teachers lead to ineffective students. Obanya (2004) discovered a substantial association between teachers' subject knowledge and academic success. Students can develop a deep affinity for a teacher who knows his subject well and is well-versed in it. According to Samson (2009), inefficient teachers lead to ineffective students to substantiate the foregoing.

It is clear from the data analysis that the principal's leadership has a substantial impact on enhancing teacher competence in an indirect manner through the dedication of teachers. This shows that the principal's leadership as the executor of educational supervision, or in other words, as a supervisor, is able to mediate the improvement of teacher competence through the application of teacher dedication.

Mart (2013) found that dedicated teachers can easily inspire students' interest in active learning and guide their intellectual and moral development to increase academic performance. Devoted teachers will also be enthusiastic in their official tasks and will have an interest in guaranteeing pupils' academic achievement. Conversely, instructors who lack dedication may perform clumsily and may not prioritize kids' academic progress, in which case the principal's role is critical in fostering effective teacher dedication.

Furthermore, the quality of teachers is a crucial component that influences children's education (Roti et al, 2020). Instructors must be changed by academic supervision to become competent, i.e., teachers must master their personal, pedagogic, professional, and social skills. Instructors are aided in managing the learning process by principals through academic monitoring, and teachers are assisted in developing their professionalism, in this instance the teacher's performance in preparing learning resources. Academic monitoring should therefore focus on the development of all teacher competencies (Susanti et al, 2020). Students also play an important part in the monitoring of their peers. There are several dynamic variables at play in the connection between lecturers and academic supervisors (Gratrix \& Barrett, 2017). As a result, it's important to find out what students' expectations of academic partnerships and the support they receive from mentors are. An essential aspect to explore is how students' ideas differ from or combine with those of their supervisors. Theory suggests that a series of activities designed to help teachers enhance their skills in managing the learning process professionally to achieve learning objectives can be derived from this research. Personality, pedagogical, professional, and social competencies are all cultivated through academic supervision.

\section{F. Conclusion}

In conclusion, this study discovered evidence that supervisory leadership has a direct and indirect impact on the discipline, dedication, and competency of English teachers in Samarinda's MTs private and public schools. Supervisory has an obvious direct effect on discipline, devotion, and competence. As a result, the indirect influence appears on supervisory via discipline, supervisory by devotion, and supervisory via competence. This study discovers a new finding: a mix of supervisory tactics based on discipline and dedication greatly improves English instructors' competence at the secondary school level. 
However, this study has limitations in that the instruments used to collect data on teacher discipline, devotion, and competence require further development of their indicators. Researchers must examine the instrument's applicability when generating findings. Future research should focus on doing a more in-depth experimental study with a focus on the development of a new questionnaire.

\section{BIBLIOGRAPHY}

Afe, JO (2001). Reflections on becoming a teacher and the challenges of teacher education. Inaugural Lecture Series 64 presented at University of Benin, Benin, Nigeria

Andriani, S., Kesumawati, N., \& Kristiawan, M. (2018). The influence of the transformational leadership and work motivation on teachers performance. International Journal of Scientific \& Technology Research, 7(7), 19-29.

Apriana, D., Kristiawan, M., \& Wardiah, D. (2019). Headmaster's competency in preparing vocational school students for entrepreneurship. International Journal of Scientific \& Technology Research, 8(8), 1316-1330.

Banjo, DS (2004). Teachers: The pillars behind the success of the educational system. Endurance Press.

Berg, G. (1989). Educational reform and teacher professionalism. Journal of curriculum studies, 21(1), 53-60.

Campbell, E. (1996). Ethical implications of collegial loyalty as one view of teacher professionalism. Teachers and Teaching, 2(2), 191-208.

Carlos, AP, Cardoso, S., Galante, S., Lamy, F., Silva, P., Gaspar, I., \& Seabra, F. (2017). Supervision in continuous teacher training. Enseñanza and Teaching: Revista Interuniversitaria de Didáctica, 35(1), 185-206.

Craig, Ashley C. \& Martin, David C.. (2019). Working Paper. "Discipline Reform, School Culture, and Student Achievement". https://scholar.harvard.edu/davidmartin/publications/discipline-reform-school-culture-and-student-achievement

Creswell, J.W. (2014). Research Design: Qualitative, Quantitative, and Mixed Methods Approaches (4 ${ }^{\text {th }}$ Ed.). SAGE Publications.

Darling-Hammond, L., Wei, RC, Andree, A., Richardson, N., \& Orphanos, S. (2017). Professional learning in the learning profession. Washington, DC: National Staff Development Council, 12.

Day, C. (2002). School reform and transitions in teacher professionalism and identity. International journal of educational research, 37(8), 677-692.

Edo, BL, \& David, AA (2019). Influence of school supervision strategies on teachers job performance in senior secondary schools in River state. International Journal of Innovative Development and Policy Studies, 7(4), 45-54.

Egwu, SO (2015). Principals' Performance in Supervision of Classroom Instruction in Ebonyi State Secondary Schools. Journal of Education and practice, 6(15), 99-105.

Furlong, J., Barton, L., Miles, S., \& Whitty, G. (2000). Teacher education in transition. Open University Press. 
Gratrix, L., \& Barrett, D. (2017). Desperately seeking consistency: Student nurses' experiences and expectations of academic supervision. Nurse Education Today, 48, 712.

Hewitt, A. (2004). Research Brief: employee engagement higher at double-digit growth companies. Hewitt Associates LLC.

Hitt, Michael A., Ireland, R. Duane., Hoskisson, Robert E. (2001) Strategic Management: Competitiveness and Globalization; Concept, First Edition. Four Salemba.

Jolayemi, OO (2008). Ways of improving students' academic performance in public secondary schools in Nigeria. Herfers Press.

Khasanah, U., Kristiawan, M., \& Tobari. (2019). The Implementation of Principals' Academic Supervision In Improving Teachers' Professionalism in the State Primary Schools. International Journal of Scientific \& Technology Research, 8(8), 1107-1115.

Klaassen, C., \& Maslovaty, N. (2010). Teachers and normative perspectives in education: An introduction. In Moral courage and the normative professionalism of teachers (pp. 112). Brill Sense.

Mangkunegara, AP, \& Octorend, TR (2015). Effect of work discipline, work motivation and job satisfaction on employee organizational commitment in the company (Case study in PT. Dada Indonesia). Marketing, 293, 31-6.

Mart, CT (2013). A passionate teacher: Teacher commitment and dedication to student learning. International Journal of Academic Research in Progressive Education and Development, 2(1), 437-442.

Mette, IM, Range, BG, Anderson, J., Hvidston, DJ, \& Nieuwenhuizen, L. (2015). Teachers' Perceptions of Teacher Supervision and Evaluation: A Reflection of School Improvement Practices in the Age of Reform. Education Leadership Review, 16(1), 1630. https://eric.ed.gov/?id=EJ1105545

Murtiningsih, M., Kristiawan, M., \& Lian, B. (2019). The Correlation Between Supervision of Headmaster and Interpersonal Communication With Work Ethos of the Teacher. European Journal of Education Studies 6(1), 246256.http://dx.doi.org/10.46827/ejes.voio. 2398

Obanya, P. (2004). The African teacher of the 21st century. Heinemann Educational BK

Oghuvbu, EP (2007). Indiscipline among Teachers: Causes and Influence on School Administration in Nigeria. Online Submissions.https://eric.ed.gov/?id=ED496281

Rahabav, P. (2016). The Effectiveness of Academic Supervision for Teachers. Journal of Education and Practice, 7(9), 47-55.https://eric.ed.gov/?id=EJ1095817

Reinecke, DR, Krokowski, A., \& Newman, B. (2018). Self-management for building independence: Research and future directions. International Journal of Educational Research, 87, 119-126. https://doi.org/10.1016/j.ijer.2016.08.006

Renata, R., Wardiah, D., \& Kristiawan, M. (2018). The Influence of Headmaster's Supervision and Achievement Motivation on Effective Teachers. International Journal of Scientific \& Technology Research, 7(4), 44-49.

Retherford, RD, \& Choe, MK (2011). Statistical models for causal analysis. John Wiley \& Sons. 
Robbins, SP (2001). Organizational Behavior. Pearson Education International.

Roseline, MB, \& Konya, KT (2019). Employee dedication and performance of transport operators in the marine sector in Port Harcourt, Nigeria. International Journal of Advanced Academic Research, 5(5), 18-33.

Roti, RS, Lumapow, HR, \& Sumual, SD (2020). Implementation Academic Supervision of Principals at Taraitak Public Elementary School Langowan District, Indonesia. IJAR, 6(7), 106-111.

Saleh, S., Arhas, S. H., Haerul, H., \& Nasaruddin, N. (2019). Utilization of Learning Media in Digital Simulation Subjects. Jurnal Office, 4(2), 79-90.

Samson, KT (2009). Causes of poor students' academic performance in Nigeria. Key Has Press.

Spencer, LM, \& Spencer, PSM (2008). Competence at Work models for superior performance. John Wiley \& Sons.

Streiner, DL (2005). Finding our way: an introduction to path analysis. The Canadian Journal of Psychiatry, 50(2), 115-122.

Sulyman, $\mathrm{KO}$ (2020). Lecturer compensation, job commitment and goal achievement in State Colleges of education, North-central Nigeria. An Unpublished Ph. D. Thesis, Department of Educational Management, University of Ilorin, Ilorin, Nigeria.

Susanti, S., Wardiah, D., \& Lian, B. (2020). Effect of Academic Supervision of School Heads and School Culture on Quality Teaching Teachers. International Journal of Progressive Sciences and Technologies, 20(1), 67-77.

Talbert, JE, \& McLaughlin, MW (1994). Teacher professionalism in local school contexts. American journal of education, 102(2), 123-153.

Ujiarto, T., Rusdarti, R., Rifai, RC, \& Raharjo, TJ (2017). Effect of The School Principal's Management, Academic Supervision, Organizational Culture, and Work Motivation to The Teacher's Professionalism. Journal of Educational Development, 5(3), 414-424.

Wairimu, MJ (2016). Teachers' perception on classroom observation and checking of pupils' exercise books by head teachers on performance of duty in primary schools in Nakuru North District, Kenya. Journal of Education \& Social Policy, 3(3), 80-87. 